\title{
Researches Regarding a Protein Hydrolysate Used as Adjuvant in Fertilization Process
}

\author{
Elena Mihaela NAGY ${ }^{1 *}$, Constantin COȚA ${ }^{1}$, Nicolae CIOICA ${ }^{1}$, Zoltan GYORGY ${ }^{1}$, Lucian FECHETE- \\ TUTUNARU ${ }^{2}$, Adina GHIRIŞAN ${ }^{3}$, Vasile MICLĂUŞ ${ }^{3}$ \\ ${ }^{1}$ INMA Bucharest, Branch Cluj-Napoca, 59 Al. Vaida Voevod Street, Cluj Napoca,Romania \\ ${ }^{2}$ Technical University of Cluj-Napoca, Faculty of Mechanics, 103-105, Muncii B-dul, Cluj Napoca, Romania \\ ${ }^{3}$ Babeş-Bolyai University, Faculty of Chemistry, 1 Arany János Street, Cluj-Napoca, Romania \\ *corresponding author, e-mail: nagy_m2002@yahoo.co.uk
}

Bulletin UASVM series Agriculture 76(2) / 2019

Print ISSN 1843-5246; Electronic ISSN 1843-5386

DOI:10.15835/buasvmcn-agr: 2018.0035

\begin{abstract}
:
Within the paper the results of conducted researches in order to obtain a protein hydrolysate from wool waste as raw material are presented. The experiments were conducted in two variants: a) alkaline hydrolyse using potassium hydroxide, a mix of potassium hydroxide with urea and a mix of potassium hydroxide with sodium hydroxide as well as b) acidic hydrolyse with sulfuric acid or a mix of sufuric acid with phosphoric acid in different proportions. The parameters intervals used were: $\mathrm{pH}$ 0,5-2,5 for acidic hydrolyse and $\mathrm{pH} 9,5-13,5$ for the alkalinic one; temperatures between $120-150{ }^{\circ} \mathrm{C}$ and pressures between 1,4-4,6 bar. Acid hydrolysis is favored by the high proportion of sulfuric acid, phosphoric acid, a low $\mathrm{pH}$ and from high temperature and pressure. The alkaline hydrolysis is favored by a pH higher then 12 as well as the urea content. A high temperature and pressure has a beneficial effect over alkaline hydrolysis.
\end{abstract}

Keywords: fertilizer, hydrolysis, protein hydrolysate

\section{INTRODUCTION}

Amino acids, peptides and polypeptides found in protein hydrolysate composition play an essential role in enzymatic and bacterial processes that occur both in soil and in plants also contributing to the degradation of pesticides and toxins (Zǎinescu et al., 2009;Sîrbu et al., 2018).

Cioroianu et al. (2011), Opricã et al. (2011) showed that the addition of protein hydrolysates in a complex mineral matrix to corn and sunflower crops leads to an increase in nitrogen content in plants and a significantly higher yield compared to the variant without protein hydrolyzate. Also, it is mentioned the use of hydrolysed proteins mixed with potassium polyphosphates to increase agricultural production by increasing phosphorus and potassium absorption (Patent US 4491464/1985).
The use of solid animal waste in order to obtain protein hydrolyzate as an adjuvant in the fertilization process is also an alternative for their elimination with a potentially low impact on the environment (Oliveira et al., 2004; Lima et al., 2010).

By-products with a high content of amino acids (over $95 \% \mathrm{w}$ ) are wool, hair or other keratinous animal ingredients. They contain, depending on their origin, a wide range of amino acids (glycine, alanine, phenylolanine, proline, threonine, arginine, lysine, tryptophan and cystine, aspartic and glutamic acids), among which the essential ones play a fundamental role in biological processes which occur both at the soil level as well as in plants.

Zoccola et al. (2015) showed that by hydrolysis in aqueous solution at high-temperature it is 
possible to convert wool waste into fertilizers in local hydrolysis plants, thus reducing transport costs for both fertilizers and wool waste for disposal them.

Research by Se Ok et al. (2011) highlighted the fact that hydrolyzate obtained from human hair contains amino acids, peptides, fatty acids and nucleotides, which together constitute an important source of nutrition by growing bacteria in the soil.

Zheljazkov (2005) conducted field experiments evaluating the potential of raw wool and hair waste as a source of nutrients for crops to improve the biological and chemical properties of the soil.

Both wool and other keratinous animal products are macromolecular complexes, mainly composed of the protein in which the amino acids are linked by peptide bonds. Under the action of physico-mechanical processes, but especially of chemical nature, these products can undergo numerous structural changes caused by breakage of peptide bonds, with amino acid formation, peptides and polypeptides and a number of other chemical compounds.

Constantinescu et al. (2015) shows how keratinous animal products (rawhide waste) can be destructured by mincing and chemical treatment at pressure and temperature above 120 ${ }^{\circ} \mathrm{C}$, in water-soluble protein hydrolysates. As a reagent for the creation of the basic environment and the breakage of the peptide bonds, he used $\mathrm{K}_{2} \mathrm{HPO}_{4} \cdot 3 \mathrm{H}_{2} \mathrm{O}$ dipotassium phosphate, technical quality.

Other results on the preparation of protein hydrolysates of animal origin, rawhide, hair, wool or wool waste, are embodied in patents (Harvey,
1985) and papers (Lima et al. 2010; Rahman, 2016; Valeika V. et al., 2018) in which the reactants are exposed, working parameters (pressure, temperature), reagent concentration and working mode.

The paper presents the results of researches undertaken for the preparation of water-soluble protein hydrolysates using as raw material wool or wool waste. The influence of working parameters (pressure, temperature), nature and concentration of reactants used for breaking the polypeptide bonds were monitored. Experiments were conducted in two variants: acid hydrolysis with sulfuric acid or a mixture of sulfuric acid and phosphoric acid in varying proportions, as well as basic hydrolysis with potassium hydroxide, a mix of potassium hydroxide with urea, and potassium hydroxide mixture with sodium hydroxide .

\section{MATERIALS AND METHODS}

Research pursued how to achieve hydrolysis, both in the acidic environment and in the basic environment, the raw unwashed wool, on which previously has not been applied physico-mechanical treatments, establishing the composition of the hydrolyzate - the organic part (amino acids, peptides and polypeptides) and the mineral part, the yield of the hydrolysis process, and $\mathrm{pH}$ evolution, depending on the type and amount of reagent used, and process parameters (temperature and pressure).

For the experiment, each sample was prepared using $75 \mathrm{~g}$ of wool waste and $450 \mathrm{ml}$ water and then treated according to Tab. 1.

Table 1. Samples prepared for experiment

\begin{tabular}{|c|c|c|c|c|c|}
\hline \multirow{2}{*}{ Material } & \multicolumn{3}{|c|}{ alkaline hydrolyse } & \multicolumn{2}{|c|}{ acidic hydrolyse } \\
\hline & $\mathrm{KOH}, \mathrm{g}$ & Urea, $g$ & $\mathrm{NaOH}, \mathrm{g}$ & $\mathrm{H}_{2} \mathrm{SO}_{4}, \mathrm{~g}$ & $\mathrm{H}_{3} \mathrm{PO}_{4}, \mathrm{~g}$ \\
\hline \multirow{9}{*}{$\begin{array}{c}75 \mathrm{~g} \text { wool waste } \\
+ \\
450 \mathrm{ml} \mathrm{H}_{2} \mathrm{O}\end{array}$} & 8 & - & - & 70 & - \\
\hline & 10 & - & - & 140 & - \\
\hline & 12 & - & - & 25 & 45 \\
\hline & 14 & - & - & 90 & 50 \\
\hline & 8 & 30 & - & - & - \\
\hline & 10 & 60 & - & - & - \\
\hline & 12 & 90 & - & - & - \\
\hline & 14 & 120 & - & - & - \\
\hline & 6 & - & 6 & - & - \\
\hline
\end{tabular}


The hydrolysis was performed for 5 hours in an autoclave provided with the possibility of adjusting the process parameters (temperature and pressure). For each sample, hydrolysis was observed for three distinct situations of process parameter values: $\mathrm{T}_{1}=120^{\circ} \mathrm{C}, \mathrm{p}_{1}=1.4 \mathrm{bar} ; \mathrm{T}_{2}=135^{\circ} \mathrm{C}$, $\mathrm{p}_{2}=2.5$ bar; $\mathrm{T}_{3}=150^{\circ} \mathrm{C}, \mathrm{p}_{3}=4.6$ bar.

\section{RESULTS AND DISCUSSIONS}

The results obtained from the experiments show that the process of hydrolysis and dissolution of the wool can be carried out in an aqueous medium, with chemical agents both under acidic conditions $(\mathrm{pH}<7)$ and under basic conditions ( $\mathrm{pH}>7)$.

\section{BASIC HYDROLYSIS}

The macromolecular complex of the wool, which is sensitive to the action of the basic reagents, undergoes important structural changes of keratin, resulting in the occurrence of a hydrolysis phenomenon resulting in breakage of peptide bonds with amino acids, peptides or polypeptides formation, characterized by molecular mass small and water-soluble. These wool destructuring processes are strongly influenced by the nature and concentration of the basic agent, temperature and reaction time. Alkaline agents may cause hydrolysis reactions in both the amide groups of asparagine and glutamine and the peptide linkages of macromolecular chains. In Tab. 2 are

Table. 2. Influence of working parameters on the process of alkaline hydrolysis of wool

\begin{tabular}{|c|c|c|c|c|c|c|c|c|c|}
\hline \multicolumn{3}{|c|}{$\begin{array}{l}\text { Material: } 75 \mathrm{~g} \text { wool waste } \\
\quad+450 \mathrm{ml} \mathrm{H}_{2} \mathrm{O}\end{array}$} & \multicolumn{2}{|c|}{$\begin{array}{c}\text { Process } \\
\text { parameters }\end{array}$} & \multicolumn{2}{|c|}{ pH } & \multicolumn{2}{|c|}{ Hydrolysate composition, g } & \multirow{2}{*}{$\begin{array}{l}\text { Yield, } \\
\%\end{array}$} \\
\hline $\mathrm{KOH}, \mathrm{g}$ & Urea, $g$ & $\mathrm{NaOH}, \mathrm{g}$ & $\mathrm{T},{ }^{\circ} \mathrm{C}$ & p,bar & initial & final & Organic part & Mineral part & \\
\hline \multirow{3}{*}{8} & \multirow{3}{*}{ - } & \multirow{3}{*}{ - } & 120 & 1.4 & \multirow{3}{*}{12.8} & 9.5 & 26.0 & \multirow{3}{*}{$6.85^{*}$} & 35 \\
\hline & & & 135 & 2.5 & & 9.4 & 36.0 & & 48 \\
\hline & & & 150 & 4.6 & & 9.1 & 64.0 & & 85 \\
\hline \multirow{3}{*}{10} & \multirow{3}{*}{ - } & \multirow{3}{*}{-} & 120 & 1.4 & \multirow{3}{*}{13.5} & 10.8 & 40.4 & \multirow{3}{*}{$8.53^{*}$} & 57 \\
\hline & & & 135 & 2.5 & & 9.9 & 51.0 & & 68 \\
\hline & & & 150 & 4.6 & & 9.7 & 71.2 & & 95 \\
\hline \multirow{3}{*}{12} & \multirow{3}{*}{-} & \multirow{3}{*}{ - } & 120 & 1.4 & \multirow{3}{*}{13.8} & 10.3 & 47.3 & \multirow{3}{*}{$10.2^{*}$} & 63 \\
\hline & & & 135 & 2.5 & & 10.1 & 66.0 & & 88 \\
\hline & & & 150 & 4.6 & & 9.7 & 73.5 & & 98 \\
\hline \multirow{3}{*}{14} & \multirow{3}{*}{ - } & \multirow{3}{*}{-} & 120 & 1.4 & \multirow{3}{*}{13.8} & 12.9 & 63.8 & \multirow{3}{*}{$11.9^{*}$} & 83 \\
\hline & & & 135 & 2.5 & & 12.8 & 73.5 & & 98 \\
\hline & & & 150 & 4.6 & & 12.5 & 75.0 & & 100 \\
\hline \multirow{3}{*}{8} & \multirow{3}{*}{30} & \multirow{3}{*}{ - } & 120 & 1.4 & \multirow{3}{*}{12.8} & 12.9 & 41.3 & \multirow{3}{*}{$24.9^{* *}$} & 55 \\
\hline & & & 135 & 2.5 & & 12.8 & 65.2 & & 87 \\
\hline & & & 150 & 4.6 & & 12.5 & 71.3 & & 95 \\
\hline & & & 120 & 1.4 & & 12.8 & 53.3 & & 71 \\
\hline 10 & 60 & & 135 & 2.5 & 13.1 & 12.7 & 69.0 & $42.85^{* *}$ & 92 \\
\hline & & & 150 & 4.6 & & 12.5 & 72.0 & & 96 \\
\hline & & & 120 & 1.4 & & 12.3 & 67.5 & & 90 \\
\hline 12 & 90 & - & 135 & 2.5 & 13.4 & 11.7 & 69.8 & $68.53^{* *}$ & 93 \\
\hline & & & 150 & 4.6 & & 11.6 & 75.0 & & 100 \\
\hline & & & 120 & 1.4 & & 12.1 & 71.3 & & 95 \\
\hline 14 & 120 & & 135 & 2.5 & 13.5 & 12.0 & 75.0 & $83.9^{* *}$ & 100 \\
\hline & & - & 150 & 4.6 & & 11.8 & 75.0 & & 100 \\
\hline & & & 120 & 1.4 & & 9.6 & 48.8 & & 65 \\
\hline 6 & - & 6 & 135 & 2.5 & 13.6 & 9.5 & 66.1 & $9.75^{* * *}$ & 85 \\
\hline & & & 150 & 4.6 & & 9.4 & 74.3 & & 93 \\
\hline
\end{tabular}

Note: Mineral part expressed trough: $\left.\left.{ }^{*}\right) \mathrm{K}_{2} \mathrm{O} ;{ }^{* *}\right) \mathrm{K}_{2} \mathrm{O}$ si $\left.\mathrm{NH}_{3} ;{ }^{* * *}\right) \mathrm{K}_{2} \mathrm{O}$ and $\mathrm{Na}_{2} \mathrm{O}$ 
presented the experimental results regarding the influence of temperature, pressure, nature and concentrations of alkaline agents and $\mathrm{pH}$ on the alkaline hydrolysis process of the wool.

Alkaline treatment of wool results in a large number of secondary reactions involving thioaminoacids, reactions that result in new functional lateral groups that react with functional groups of amino acids or peptides to form insoluble compounds, which determine the decreaseing of dissolution yields. The chemical reactions and structural changes suffered by wool are, on the other hand, heavily influenced by different treatments applied prior to the hydrolysis process (oxidation reactions, reduction, thermal treatments, etc.).

The experimental data shows a strong influence of the temperature and concentration of the basic agent used on the degree of hydrolysis. Thus, at $\mathrm{KOH}$ solution concentrations lower than $2.7 \%$, the wool hydrolysis is not entirely achieved at $150{ }^{\circ} \mathrm{C}$ in a reaction time of 5 hours. At $3 \%$ concentration of $\mathrm{KOH}$ solution we obtain for hydrolysis yields $98 \%$ even at $\mathrm{T}=135{ }^{\circ} \mathrm{C}$ and pressure $\mathrm{p}=2.5 \mathrm{bar}$ and at $150{ }^{\circ} \mathrm{C}$ the solubility degree of wool reaches $100 \%$.

A strong influence on the degree of wool hydrolysis is shown the addition of urea. The urea introduced into the reagent mass composition favors the hydrolysis process by interposed betwe- en the peptide strong chains inside the yarns reducing the strength of the hydrogen bonds so they fragment. In addition, the low basic character of urea causes a decrease in lateral electrovalent (ionic) bonds and the interaction between the acidic group - $\mathrm{COOH}$ and the amide- $\mathrm{NH}$ group within the macromolecules.

At concentrations of less than $2 \%$ of the basic agent in the mass of the reagent, we see an important fragmentation of the wool but with a dissolution yield ranging between $35-15 \%$.

The major disadvantage of basic hydrolysis lies in the large number of side reactions that specifically affect thio-aminoacids, thus reducing the content of cystine and methionine.

\section{Acidic hydrolysis}

The results on the influence of temperature, pressure, nature and acid concentration on the degree of wool solubility are presented in Tab. 3 .

Preliminary research with dilute solutions of $\mathrm{H}_{2} \mathrm{SO}_{4}(<10 \%)$ at boiling temperature showed that the degree of destruction and dissolution of wool is insignificant even after 10 hours. At higher concentrations of sulfuric acid (13.5\%), solubility yields are obtained, which increase with temperature, from $28 \%$ to $43 \%$. At the same time, there is also a process of destruction by segmenting wool yarns, which become smaller the higher the temperature is. As the acid solution

Table. 3. Results obtained at acid hydrolysis of wool

\begin{tabular}{|c|c|c|c|c|c|c|c|c|}
\hline \multicolumn{2}{|c|}{$\begin{array}{l}\text { Material: } 75 \mathrm{~g} \text { wool waste } \\
\quad+450 \mathrm{ml} \mathrm{H}_{2} \mathrm{O}\end{array}$} & \multicolumn{2}{|c|}{$\begin{array}{c}\text { Process } \\
\text { parameters }\end{array}$} & \multicolumn{2}{|c|}{ pH } & \multicolumn{2}{|c|}{ Hydrolysate composition, g } & \multirow{2}{*}{$\begin{array}{l}\text { Yield, } \\
\%\end{array}$} \\
\hline $\mathrm{H}_{2} \mathrm{SO}_{4}, \mathrm{~g}$ & $\mathrm{H}_{3} \mathrm{PO}_{4}, \mathrm{~g}$ & $\mathrm{~T},{ }^{\circ} \mathrm{C}$ & p,bar & initial & final & Organic part & Mineral part & \\
\hline \multirow{3}{*}{70} & & 120 & 1.4 & \multirow{3}{*}{0.1} & 2.0 & 21.0 & \multirow{3}{*}{$70^{*}$} & 28 \\
\hline & - & 135 & 2.5 & & 2.3 & 26.3 & & 35 \\
\hline & & 150 & 4.6 & & 2.5 & 32.3 & & 43 \\
\hline \multirow{3}{*}{140} & \multirow{3}{*}{ - } & 120 & 1.4 & \multirow{3}{*}{0.5} & 1.2 & 27.0 & \multirow{3}{*}{$140^{*}$} & 36 \\
\hline & & 135 & 2.5 & & 1.4 & 31.5 & & 42 \\
\hline & & 150 & 4.6 & & 2.0 & 58.5 & & 78 \\
\hline \multirow{3}{*}{25} & \multirow{3}{*}{45} & 120 & 1.4 & \multirow{3}{*}{1.0} & 2.1 & 20.3 & \multirow{3}{*}{$70^{* *}$} & 27 \\
\hline & & 135 & 2.5 & & 2.2 & 27.0 & & 36 \\
\hline & & 150 & 4.6 & & 2.7 & 31.5 & & 42 \\
\hline \multirow{3}{*}{45} & \multirow{3}{*}{90} & 120 & 1.4 & \multirow{3}{*}{0.5} & 1.5 & 28.5 & \multirow{3}{*}{$140^{* *}$} & 38 \\
\hline & & 135 & 2.5 & & 2.0 & 34.3 & & 46 \\
\hline & & 150 & 4.6 & & 2.5 & 61.4 & & 83 \\
\hline
\end{tabular}

Note: Mineral part expressed trough: $\left.\left.{ }^{*}\right) \mathrm{H}_{2} \mathrm{SO}_{4} ;{ }^{* *}\right)_{2} \mathrm{H}_{2} \mathrm{SO}_{4} \mathrm{si} \mathrm{H}_{3} \mathrm{PO}_{4}$ 
concentration increases to $23 \%$, the degree of solubility, depending on temperature, rises from $36 \%$ to $78 \%$.

Hydrolysis with a mixture of $\mathrm{H}_{2} \mathrm{SO}_{4}-\mathrm{H}_{3} \mathrm{PO}_{4}$, with a total acid concentration of $13.5 \%$, leads to results similar to those when the hydrolysis process was carried out with $\mathrm{H}_{2} \mathrm{SO}_{4}$ solutions at a concentration of $13.5 \%$. By increasing the concentration of $\mathrm{H}_{2} \mathrm{SO}_{4}-\mathrm{H}_{3} \mathrm{PO}_{4}$ solution to $22.2 \%$, the yield of wool dissolution increases significantly to values comparable to those in which hydrolysis was performed with $\mathrm{H}_{2} \mathrm{SO}_{4}$ at a concentration of $23 \%$.

The overall hydrolysis analysis of the macromolecular complex of the wool shows that the determinant role in the process is acid concentration. As the concentration of acidic solution increases, the degree of destruction and dissolution of the wool increases.

The partial replacement of $\mathrm{H}_{2} \mathrm{SO}_{4}$ with $\mathrm{H}_{3} \mathrm{PO}_{4}$ shows a practical importance in terms of the quality and efficiency of the hydrolyzate obtained in that it additionally contains $\mathrm{P}$, essential macroelement in the fertilization process.

The acid hydrolysis process is accompanied by high energy consumption to break the amide bonds and, as a result, is favored by high temperature. On the other hand, the acid hydrolysis of the bonds in the macromolecular structure of the wool is a process that involves equilibrium reactions that are carried out more difficult, at a lower speed.

The displacement of the equilibrium towards the formation of amino acids, peptides and polypeptides of low molecular weight, soluble in water, involves excessive acid use, which can cause serious corrosion problems for equipment and work installations.

\section{CONCLUSION}

Obtaining protein hydrolyzate from wool waste for use as an adjuvant in the fertilization process is achievable in both acidic and alkalin media, giving better yields in case of alkalin hydrolysis.

Process parameters, temperature and pressure influence the process of hydrolysis, higher values lead to increased yield.

In the case of alkaline hydrolysis, the addition of urea to potassium hydroxide increases the efficiency of the hydrolysis process, both in terms of yield and of the organic component of the hydrolyzate.

In acidic hydrolysis, the mixture of sulfuric acid and phosphoric acid increase the efficiency of the hydrolysis process from yield point of view.

Acknowledgments. This work was supported by 1 founding source: Ministry of Research and Innovation, Project NUCLEU code PN 18300103.

\section{REFERENCES}

1. Cioroianu T, Sîrbu C, Oprica I, Grigore A, Mihalache D, Dumitrascu M, Anton I, Soare M (2011). Fertilizers with protein substances, technology, agro-chemical and physical characteristics. Agricultural Management, I(XIII): 449-453.

2. Constantinescu RR, Zainescu G, Stefan D S, Sîrbu C, Voicu P (2015). Protein Biofertilizer Development and Application on Soybean Cultivated Degraded Soil. Revista de Pielarie Incaltaminte, 15( 3): 171-178.

3. Harvey H (1985). Potassium polyphosphate protein hydrolysate fertilizer. Patent US 4491464.

4. Lima DQ, Oliveira LCA, Bastos ARR, Carvalho GS, Marques JGSM, Carvalho JG, Souza GA (2010). Leather Industry Solid Waste as Nitrogen Source for Growth of Common Bean Plants. Applied and Environmental Soil Science, 344-347.

5. Oliveira LCA, Dallago RM, Nascimento Filho I (2004). Process of recycling leather tanning solid residues by chrome extraction and recuperation of the decontaminated. Patent BR PI 001538.

6. Opricã I, Sîrbu C, Cioroianu T, Soare M, Grigore A, Marin $N$ (2011). The influence of foliar fertilizer with organic substances on phosphorus content in maize plant, Research Journal of Agricultural Science. 43(3), 150-153.

7. Rahman M (2016). Quick Release Nitrogenous Fertilizer from Human Hair, British Journal of Applied Science \& Technology, 14(2): 1-11.

8. Se Ok OH, Yun A, Park D (2011). Effects of Physicochemically Hydrolyzed Human Hairs on the Soil Microbial Community and Growth of the Hot Pepper Plant, Biotechnology and Bioprocess Engineering 16: 746-754.

9. Sirbu C, Cioroianu T, Marin N, Rujoi B (2018). Liquid fertilizers with organic substances - Agrochemical effects obtained by application. Revista de Chimie -Bucharest, 69(6): 1478-1484 .

10. Valeika V, Jankauskaitė V, Beleška K, Valeikienè V (2018). Biodegradability Of Hair As A Waste Of Leather Industry. 
Proceedings of ICAMS-7 $7^{\text {th }}$ International Conference on Advanced Materials and Systemshttps, VIII, 15.

11. Zãinescu G, Voicu P, Gherghina CA, Sandru L (2009). Exploratory Research Regarding the Use of Organic
Biopolymers from Tanneries in Agriculture - Part I. Revista de Pielarie, 9(4): 258-265.

12. Zheljazkov VD (2005). Assessment of Wool Waste and Hair Waste as Soil Amendment and Nutrient Source, Journal of Environmental Quality, 34(6): 2310-2317. 